\title{
STUDIES ON ANTI-COMPONENT 5 ANTIBODIES IN ANIMALS INFECTED WITH TRYPANOSOMA CRUZI
}

\section{F. Santoro', M. Sadigursky2, I. Sherlock2, D. Afchain'1 and A. Capron1}

\begin{abstract}
A competitive antibody enzyme immunoassay, using a monoclonal antibody against the species-specific Trypanosoma cruzi antigen 5, was used to investigate the presence of anti-component 5 antibodies in sera of opossums, dogs, rabbits and rats infected with this parasite. The sera from 51 venezuelan patients with Chagas'disease were also tested. About $90 \%$ of the infected subjects showed significant levels of anti-component 5 antibodies. Nevertheless, these antibodies were not detected in the sera of dogs, rats and opossums infected with $\mathrm{T}$. cruzi Some sera from infected rabbits presented significant results but close to the limit of positivity of the test. These findings suggest that the immune response in animals naturally or experimentally infected with $\mathrm{T}$. cruzi is different from that observed in human Chagas'disease.
\end{abstract}

Key words: Trypanosoma cruzi. Antibodies. Immunoassay.

The association of Trypanosoma cruzi with T. rangeli 1123 or leishmanial infections ${ }^{12} 13$, has been reported many areas of Central and South America. As there are important antigenic cross-reactivities between these different parasites ${ }^{38}$ the use of classical serological tests for the diagnosis of Chagas'disease becomes ineffective in these coendemic areas. In an attempt to gain better specificity for diagnosis, several technical approaches have been used 910142122 .

In previous studies, Afchain et al ${ }^{3}$ have identified a species-specific antigen called component 5 , in the $T$. cruzi parasite. Recently, by using murine monoclonal antibodies directed against this component ${ }^{1819}$, Lemesre et al 16 proposed a competitive enzyme immunoassay (CEIA) for the specific diagnosis of Chagas'disease. The purpose of the present work was to use the CEIA to investigate anti-component 5 antibodies in sera of dogs, rabbits, opossums and rats infected with $T$. cruzi and to compare it with that find in patients with American trypanosomiasis.

\section{MATERIALS AND METHODS}

\section{Animal sera}

Twenty-eight mongrel dogs of both sexes, $2-5$ months old, were inoculated intraperitoneally with 4-6 $\times 10^{5} T$. cruzi trypomastigotes of the $12 \mathrm{SF}$ strain per $\mathrm{kg}$ of body weight as described by Andrade et $\mathrm{al}^{4}$. They all developed positive parasitaemias at 5-7 days

1. Centre d'Immunologie et de Biologie Parasitaire (Unité Mixte INSERM U 167 - CNRS 624), Institut Pasteur, 1, rue du Prof. A. Calmette, 59019 LILLE Cédex, France.

2. Centro de Pesquisas Gonçalo Moniz (FIOCRUZ/UFBa), 40000 Salvador, Bahia, Brazil.

Recebido para publicação em 1./8/86 after inoculation and sera were collected at different times of both the acute and the chronic phase of the infection. Although parasitaemia became negative at the chronic stage, xenodiagnosis and/or the complement fixation test remained positive for all animals. A total of 40 serum samples of infected dogs was used in this study. The sera from 14 dogs before inoculation were used as control.

Thirteen New Zealand white rabbits, weighing $1200-1500 \mathrm{~g}$, were inoculated intraperitoneally with $10^{7}$ blood stream forms of $T$. cruzi (12 SF strain) per $\mathrm{kg}$ of body weight. Parasitaemias in the acute phase, and positive xenodiagnosis and indirect immunofluorescence in the chronic phase confirmed the infection. A total of 24 serum samples collected at several times after inoculation was used in this study. Seven preinoculation sera from the same rabbits were used as control.

Fifteen male Fischer rats, weighing $180-200 \mathrm{~g}$ were inoculated intraperitoneally with $1 \mathrm{ml}$ heparinized rat blood containing $10^{4} \mathrm{~T}$. cruzi trypomastigotes of the Tehuantepec strain as described by Rodriguez et $\mathrm{al}^{20}$. The infection was monitored by the presence of parasites in the blood and by a positive passive hemagglutination test ${ }^{19}$. A total of 15 serum samples was collected at different times after infection. The sera from 8 normal Fischer rats were used as control.

The sera from 25 opossums (Didelphis albiventris), captured in an endemic area for Chagas'disease (Castro Alves, Bahia state, Brazil) have also been studied. Twelve were naturally infected with $T$. cruz $i$ as confirmed by a positive xenodiagnosis. The sera from 14 opossums, captured in a non-endemic area for Chagas'disease (Jacobina, Bahia state, Brazil) and with a negative xenodiagnosis, were used as control. Two of them showed a positive culture for Leishmania spp. 


\section{Human sera}

The sera from 51 Venezuelan patients with chronic Chagas'disease and a positive serology for $T$. cruzi (immunofluorescence, complement fixation test, hemagglutination and ELISA) were generously provided by Dr. Rosa M. Mübsch, Universidad de Carabobo, Facultad de Ciencias de la Salud, Maracay, Venezuela. Control sera were obtained from 20 healthy subjects with a negative serology for $T$. cruzi.

\section{Monoclonal antibody (mAb)}

Hybridomas secreting mAb against component 5 has been described by Orozco et all 18 19. Ascitic fluid were produced in Balb/c mice and the $\mathrm{mAb}$ (II$190 / 30$ ) was purified by a $50 \%$ ammonium sulfate precipitation followed by a ion exchange chromatography on DEAE-Trisacryl (IBF, Villeneuve la Garenne, France). Labelling of purified mAb with alkaline phosphatase (grade I from calf intestine, Boehringer, Mannheim, West Germany) was performed by the one-step glutaraldehyde method of Avrameas ${ }^{5}$. Briefly: to $5 \mathrm{mg}$ of enzyme were added $1 \mathrm{ml}$ of the $\mathrm{mAb}$ solution $(2 \mathrm{mg} / \mathrm{m} 1)$ and $10 \mu 1$ of $20 \%$ glutaraldehyde solution. The mixture was allowed to react for $2 \mathrm{~h}$ at room temperature and then dialysed against PBS.

Competitive antibody enzyme immunoassay (CEIA)

It was performed as described by Lemesre et al ${ }^{16}$. Briefly, polypropylene beads (Seroa, Monaco) were coated overnight at room temperature with a component 5-enriched $T$ cruzi antigen. After 3 washes in PBS containing $0.1 \%$ Tween 20 , the beads were incubated for $2 \mathrm{hr}$ with PBS- $0.1 \%$ bovine serum albumin, washed 3 times with PBS-Tween and once with PBS. CEIA was carried out in disposable polystyrene tubes. Coated beads were incubated for $3 \mathrm{hr}$ at $37^{\circ} \mathrm{C}$ in $350 \mu 1$ of PBS containing the labeled $\mathrm{mAb}$ (final dilution $1 / 800$ ) and the test sera (final dilution $1 / 20$ ). After 3 washes in PBS-Tween, the beads were transfered to another tube and the labelled antibody fixed to them was revealed by adding $300 \mu 1$ of the enzyme-substrate $(1 \mathrm{mg} / \mathrm{ml}$ 4-paranitrophenylphosphate in $0.5 \mathrm{M} \mathrm{Na}_{2} \mathrm{CO}_{3}, 0.001 \mathrm{M} \mathrm{MgCl}_{2}$ buffer $\mathrm{pH}$ 10.4). After contact for one hour at $37^{\circ} \mathrm{C}$, the colour development was stopped by adding $300 \mu 1 \mathrm{NaOH}$ $2 \mathrm{~N}$ and absorbance was measured at $405 \mathrm{~nm}$. As the CEIA involves the competitive inhibition of binding of alkaline phosphatase-conjugated $\mathrm{mAb}$ by anti-component 5 antibodies present in test sera low extinction values indicate a positive result.

\section{Immunoelectrophoresis}

The presence of anti-component 5 antibodies in sera of some animals infected with $T$. cruzi was also investigated by immunoelectrophoresis as described by Afchain et al ${ }^{1}$.

\section{RESULTS}

The presence of anti-component 5 antibodies in sera of dogs, rabbits, rats and opossums infected with $T$. cruz $i$ was investigated by the competitive antibody enzyme immunoassay (CEIA) with enzyme-conjugated anti-component $5 \mathrm{mAb}$ (Fig. 1). The limit of

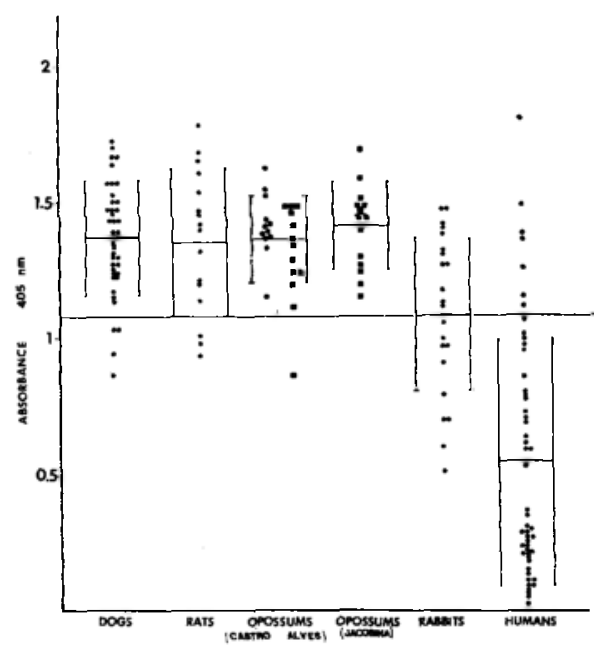

Figura 1 -Study of anti-component 5 antibodies in dogs, rats, opossums, rabbits and patients infected with Trypanosoma cruzi using a competitive enzyme immunoassay (CEIA) with a monoclonal antibody. Opossums-Jacobina: non-endemic area for Chagas'disease. Opossums-Castro Alves: endemic area for Chagas'disease ( $\mathrm{D}$ - negative xenodiagnosis).

positivity for each animal species studied was calculated in each control group as the mean subtracted of twice the standard deviation. The results were then slightly corrected in order to have the same cut-off value as that observed with normal human sera. Therefore, the data obtained for each group of animals infeted with $T$. cruzi could be compared in the same Figure 1 with the results from the patients with Chagas'disease (positive control). In these conditions, anti-component 5 antibodies were not detected in sera of dogs, rats and opossums infected with $T$. cruzi. In fact, only 4 out of 40 sera of dogs, 1 out of 13 opossums with negative xenodiagnosis, and 3 out of 15 sera of rats showed significant results which were near the limit of positivity. In the group of rabbits infected with $T$. cruzi, about the half of 
the tested sera presented a significant positive value, but most of them was closed to the limit of positivity. There was no association between these results and the phase of the infection.

To analyse further the presence of anti-component 5 antibodies in experimental Chagas'disease, the sera of the infected animals showing a significant result in the CEIA were tested by immunoelectrophoresis against a crude antigenic extract of $T$. cruzi. Although most of the sera from infected animals recognised different components in the $T$. cruzi extract, none of them reacted with the component 5 (data not shown).

\section{DISCUSSION}

A previous study demonstrated that more than $90 \%$ of patients with Chagas'disease presented significant high levels of anticomponent 5 antibodies ${ }^{16}$. In the present investigation, by using the same methodology, the CEIA with enzyme-conjugated $\mathrm{mAb}$ we have confirmed these findings in another group of patients but failed to detect significant levels of anti-component 5 antibodies in dogs, rats, opossums and rabbits infected with $T$. cruzi.

The interest in component 5 begun when Afchain et al ${ }^{1}$ showed that this antigen represents one of the major immunoelectrophoretic lines recognized by the sera of most of the patients with Chagas'disease. Furthermore, it has been demonstrated that component 5 is a species-specific antigen of $T$. cruzi ${ }^{2}$. The generation of $\mathrm{mAb}$ against this antigen allowed the identification of a $72,000 \mathrm{Mr}$ glycoprotein and its maturation products of $51,000,43,000$ and $24,000 \mathrm{Mr}$ as the molecules containing the antigenic determinants of component $5^{19}$. In order to avoid the crossreactivities frequently observed between $T$. cruz $i$ and others trypanosomatidae ${ }^{3}{ }^{8}$, Breniere et al $^{7}$ and Lemesre et al 16 have successfully used different techniques to detect anti-component 5 antibodies in sera of patients infected with $T$. cruzi. These methods have proved to be useful for the differential immunodiagnosis of human Chagas'disease.

The importance of different mammalian species as reservoir hosts in American trypanosomiasis has been showed by several investigators ${ }^{6}$. As there area many areas in Central and South America in which Chagas' disease is coendemic with other trypanosomatidae infections ${ }^{1323}$, the detection of anticomponent 5 antibodies in wild reservoirs would be important for epidemiological purposes. Nevertheless, in the present study by using a highly sensitive technique, the CEIA, we were unable to find this antibody in opossums naturally infected with $T$. cruzi. In addition, dogs and rats experimentally infected with this parasite did not present significant levels of anti-component 5 antibodies. Finally, the detection of lower levels of this antibody in some sera of rabbits infected with $T$. cruzi could not be confirmed by immunoelectrophoresis, a less sensitive technique.

In previous studies, Kirchhoff et al ${ }^{15}$ have shown that the expression of a surface antigen identified by a mAb differs among strains and clones of $T$. cruzi. This suggests that strain-specific immune responses can occur during the infection. Nevertheless, the anti-component $5 \mathrm{mAb}$ generated against the Tehuantepec strain of $T$. cruzi ${ }^{19}$ also reacted with the $12 \mathrm{SF}$ strain (Andrade et al : in preparation) used here to infect dogs and rabbits. Moreover, in the present work, the rats were infected with the same strain used to produce the $\mathrm{mAb}$. Therefore, the possibility of a strain-specific immune response against component 5 as an argument to explain the absence of anti-component 5 antibodies in dogs, rats and rabbits infected with $T$. cruzi is excluded.

The presence of anti-component 5 antibodies in sera of patients with Chagas'disease and their absence in animals naturally and experimentally infected with $T$. cruzi argue in favour of a different immune response during the animal infection as compared to that in human beings. Probably, component 5 is not immunogenic in various animals infected with $T$. cruz $i$. It is noteworthy that sera from rabbits ${ }^{7}$ and mice ${ }^{19}$ immunized with antigenic extracts of $T$. cruz $i$ recognized strongly this antigen. Our results can be related to a recent observation by Lemesre et $\mathrm{al}^{17}$ showing that the humoral immune response in mice infected with Leishmania chagasi is different from that noticed in patients with kala-azar. All these findings argue against the use of animals experimentally infected with trypanosomatidae as immunological or immunopathological models of the disease.

\section{RESUMO}

Foi usado um teste imunoenzimático competitivo para investigar a presença de anticorpos anticomponente 5 nos soros de sariguês, cães, coelhos e ratos infectados como Trypanosoma cruzi Neste teste, foi utilizado um anticorpo monoclonal contra o antígeno 5 que é especifico do T. cruzi. Também foram testados os soros de 51 pacientes venezuelanos com doença de Chagas.

Apesar desses anticorpos não serem detectados nos soros de cães, ratos e sariguês infectados com o T. cruzi, alguns soros de coelhos infectados apresentaram resultados positivos porém em niveis próximos aos do limite de positividade do teste. Esses achados sugerem que a resposta imune em animais naturalmente ou experimentalmente infectados com o T. cruzi é diferente daquela que é observada na doença de Chagas humana.

Palavras chaves: Trypanosoma cruzi. Anticorpos. Imuno-ensaio. 


\section{ACKNOWLEDGEMENTS}

This work was supported by grants from the UNDP/World Bank/WHO Special Programme for Research and Training in Tropical Diseases. The authors are indebted to Dr. Rosa M. Hübsch, Universidad de Carabobo, Maracay, Venezuela who generously provided the sera of patients with Chagas'disease. We also thank the expert technical assistance of Marc Loyens and Vera Vidal and the secretarial help of Claudine Colson.

\section{REFERENCES}

1. Afchain D, Capron A, Prata A. Les anticorps précipitantes dans la trypanosomiase humaine. Gazeta Médica da Bahia 70: 141-147, 1970.

2. Afchain D, Fruit J, Yarzabal L, Capron A. Purification of a specific antigen of Trypanosoma cruzi from the culture forms. American Journal of Tropical Medicine and Hygiene 27:478-482, 1978.

3. Afchain D, Le Ray D, Fruit J, Capron A. Antigenic make-up of Trypanosoma cruzi culture forms: identification of a specific component. Journal of Parasitology 65:507-514, 1979.

4. Andrade ZA, Andrade SG, Sadigursky M. Damage and healing in the conducting tissue of the heart (an experimental study in dogs infected with Trypanosoma cruzi). Journal of Pathology 143:93-101, 1984.

5. Avrameas S. Coupling of enzymes to proteins with glutaraldehyde. Use of the conjugates for the detection of antigens and antibodies. Immunochemistry 6: 43-52, 1969.

6. Barreto MP. Epidemiologia. In: Trypanosoma cruzi e Doença de Chagas.Brener Z \& Andrade Z (eds.), Guanabara Koogan SA, Rio de Janeiro pp. 89-151, 1979.

7. Brenière FS, Carrasco R, Moinedo S, Lemesre JL, Desjeux P, Afchain D, Carlier Y. Specific immunodiagnosis of Chagas'disease: immunodiffusion test using a specific serum anti-Trypanosoma cruz $i$ component 5. Tropical and Geographical Medicine, in press.

8. Bronzina AA, D'Alessandro A, Segura E. Differencias y similitudes antigenicas entre Trypanosoma rangeli y Trypanosoma cruzi. Medicina (Buenos Aires) 40:4549, 1980.

9. Camargo ME, Rebonato C. Cross-reactivity in fluorescence tests for Trypanosoma and Leishmania antibodies. A simple inhibition procedure to ensure specific results. American Journal of Tropical Medicine and Hygiene 18:500-505, 1969.

10. Cerisola JA, Alvarez M, Bock M, Wegner D. A comparison of a new antigen from amastigotes of Trypanosoma cruz $i$ and an antigen from epimastigotes for the diagnosis of Chagas'disease by the indirect immunofluorescence test. Revista do Instituto de Medicina Tropical de São Paulo 13:162-166, 1971.

11. D'Alessandro A. Biology of Trypanosoma (Herpetosoma) rangeli. In: Biology of the Kinetoplastida. Lumsden WHR \& Evans DA, (ed.), Academic Press, London pp. 328-403, 1979.
12. Desjeux P, Quilici M, Lapierre J. A propos de 113 cas de leishmaniose cutanée et cutanéo-muqueuse observés en Bolivie. Etude séro-immunologique de 71 cas. Bulletin de la Société de Pathologie Exotique 67:387-395, 1974.

13. Desjeux P, Aranda E, Aliago O, Mollinedo S. Human visceral leishmaniasis in Bolivia: first proven case from "Los Jungas". Transactions of the Royal Society of Tropical Medicine and Hygiene 77:851-852, 1983.

14. Guimarães MC, Celeste BJ, Ayres EC, Mineo JR, Diniz JMP. Immunoenzymatic assay (Elisa) in mucocutaneous leishmaniasis, Kala-azar and Chagas'disease: an epimastigote Trypanosoma cruzi antigen able to distinguish anti-Trypanosoma and anti-Leishmania antibodies. American Journal of Tropical Medicine and Hygiene 30:942-947, 1981.

15. Kirchhoff LV, Engel JC, Dvorak JA, Sher A. Strains and clones of Trypanosoma cruzi differ in their expression of a surface antigen identified by a monoclonal antibody. Molecular and Biochemical Parasitology 11:81-89, 1984.

16. Lemesre JL, Afchain D, Orozco O, Loyens M, Brenière FS, Desjeux P, Carlier Y, Martin V, Nogueira-Queiroz J.A, Le Ray D, Capron A. Specific and sensitive immunological diagnosis of Chagas'disease by competitive antibody enzyme immunoassay using a Trypanosoma cruzi specific monoclonal antibody. American Journal of Tropical and Medicine and Hygiene 35:8693, 1986.

17. Lemesre JL, Rizvi FS, Afchain D, Sadigursky M, Capron A, Santoro F. Subspecies-specific surface antigens of the Leishmania donovani complex. Infection and Immunity 50:136-141, 1985.

18. Orozco O, Afchain D, Rodriguez C, Ovlaque G, Loyens M, Capron A. Production d'un anticorps monoclonal anti-antigène 5 de Trypanosoma cruzi. Compterendus de l'Académie des Sciences de Paris (Série III) 295:783-785, 1982.

19. Orozco O, Afchain D, Dissous C, Rodriguez C, Ovlaque G, Lemesre JL, Loyens M, Capron A. Different monoclonal antibodies against the component 5 specific for Trypanosoma cruzi. American Journal of Tropical Medicine and Hygiene 33:560-568, 1984.

20. Rodriguez AM, Santoro F, Afchain D, Bazin H, Capron A. Trypanosoma cruzi infection in B-celldeficient rats. Infection and Immunity 31:524-529, 1981.

21. Scharfstein J, Rodrigues MM, Andrade-Alves C, Souza W, Previato JO, Mendonça-Previato L. Trypanosoma cruz $i$ : description of a highly purified surface antigen defined by human antibodies. Journal of Immunology 131:972-976, 1983.

22. Schechter, M, Voller, A, Marinkelle CJ, Flint JE, Guhl F, Miles MA. Purified Trypanosoma cruzi specific glycoprotein for discriminative serological diagnosis of south American tripanosomiasis (Chagas'disease). Lancet 2:934-941, 1983.

23. Souza OE, Johnson CM. Frequency and distribution of Trypanosoma cruzi in the Republic of Panama. American Journal of Tropical Medicine and Hygiene 20: 405-410, 1971. 